\title{
Sites of Desire:
}

\section{Chandrapore-Mayapore-Jummapur: Race, Sexuality and Law in Colonial India}

\author{
Tutun Mukherjee \\ University of Hyderabad, Hyderabad, India \\ Email: tutunmukherjee@gmail.com
}

How to cite this paper: Mukherjee, T. (2017). Sites of Desire: Chandrapore-Mayapore-Jummapur: Race, Sexuality and Law in Colonial India. Advances in Literary Study, 5, 123-142.

https://doi.org/10.4236/als.2017.55010

Received: September 25, 2017

Accepted: November 25, 2017

Published: November 28, 2017

Copyright $\odot 2017$ by author and Scientific Research Publishing Inc.

This work is licensed under the Creative

Commons Attribution International

License (CC BY 4.0).

http://creativecommons.org/licenses/by/4.0/

\section{c) (i) Open Access}

\begin{abstract}
The three selected texts by E. M. Forster, 1924 (A Passage to India Forster, 1924), Paul Scott, 1983 (Jewel in the Crown 1983), and Top Stoppard, 1995 (Indian Ink 1995) explore the complex interweaving of race, sexuality and law in colonial India suggesting the interpolation of subliminal desire that affected the relationship of the colonizers and the colonized. This essay focuses upon the intervention of race and sex in these narratives that defined the relationship between the colonizer and the colonized which have not be adequately discussed earlier. The narratives reveal the fraught and ambiguous attitude of the British colonizers towards the "natives" as objects of sexual desire though infected by the threat of racial contamination and miscegenation. Hence, such relations were either to be shunned or controlled by law. It has also been suggested that imperial administration may have used "sexual relations" as central political mechanism to control its subject population. The point to note is that the sexual gaze was in many instances reciprocal and the colonizer was also an object of desire for the colonized. The selected narratives explore three sites where the play of desire and their culmination take place.
\end{abstract}

\section{Keywords}

European Colonialism, Colonial India, Race, Sexuality, Desire, Colonial Law, E. M. Forster, Paul Scott, Tom Stoppard

\section{Introduction}

Oh, East is East, and West is West, and never the twain shall meet/Till Earth and Sky stand presently at God's great Judgment Seat/But there is neither East nor West, Border, nor Breed, nor Birth/When two strong men 
stand face to face, tho' they come from the ends of the earth! -Rudyard Kipling (1889), "The Ballad of East and West".

Although the dynamics of European colonialism and the practices of imperialism have been discussed and critiqued widely, the emotional liaisons that shaped the material worlds of the empire invite more investigation. European colonialism across the world changed the lives of the colonized people and impacted their living condition, culture, religion, economy, attitudes and thinking in profound ways, the effects of which are felt long after the colonizers left those dominions. It needs no reiteration that the analysis of the colonial context taken as a system for the exercise of power had strong and far-reaching ramification and impact and therefore is relevant for understanding the past's relationship with the postcolonial present. In his path breaking study on Orientalism, Edward Said (1978) maintained that such understanding would reveal the construction of ideologies by the Western colonizers of the non-West/non-White worlds regarding matters of race and gender. It is equally true that all intimate relationships or sexual transgressions held an undercurrent of racial and class anxiety and a threat to the racial purity of the White colonizers, besides the fear of miscegenation (see Bryder, 1998). It has been argued that the colonizers sought to create a passive sexualized native in the territories under their control which, ironically, also introduced a provocative element. As such, the "native subject" was actually a construction of the mysterious and exotic sexual imaginings of the European mind as it encountered during its colonial explorations the so-called "savage worlds" of the non-West and was caught in its own erotic projection of native sexuality of both "native" men and women as "noble savages" whose virile and seductive bodies held exotic allure and suggested yet unexplored realms of physical pleasure. Richard Berstein cites Richard F. Burton's description of the newly explored lands and writes that "For Burton, India, the Middle East, and Africa were all places of the sexual "artists" where the cultivation of love far surpassed the low and unsatisfactory levels attained in frigid Christian Europe. The East was a place where the erotic and the poetic mingled, where stripped of its taint of immorality, it could be the subject of a kind of connoisseurship, a learned cultivation" (107). Said (1978) argued that the sexual subjection of Oriental women to Western men "fairly stands for the pattern of relative strength between East and West and the discourse about the Orient that it enabled" (6) and that Orientalism takes perverse shape as male power fantasy sexualizes a feminized Orient for Western power and possession. The attitude doesn't seem to have changed much. Even now, the imagining and resourcing of Asian femaleness by White masculinity remains a social and cultural reality with routine stereotyping, exoticizing and objectification of Asian women with regularly repeated descriptions such as "submissive"; "sensual," "exotic," "feminine," "eager to please" [see Sheridan Prasso, 2005; Richard Bernstein, 2009]. In her article on "White Sexual Imperialism: A Theory on Asian Feminist Jurisprudence," Sunny Woan (2008) of Santa Clara University argues, "White sexual imperialism, through colonialism, rape and war, created the hyper-sexualized stereotype 
of the Asian woman. This stereotype in turn fostered the over-prevalence of Asian women in pornography, the mail-order bride phenomenon, the Asian fetish syndrome, and worst of all, sexual violence against Asian women" (278). Indeed, the exploitative, militaristic and violent conquest and dispossession that accompanied the project of colonialism leading to the expansion and consolidation of western imperial design were invariably and predictably linked with inter-racial and inter-ethnic confrontation resulting in inevitable emotional and psychological conflicts as evident in colonial narratives, and especially in the texts selected for discussion here. This research paper attempts to study and analyze through the selected narratives the intervention of race and sex that defined the relationship between the colonizer and the colonized, to the extent of formulation of laws by the colonizers to regulate and control individual lives. This subject has not been adequately discussed earlier.

\section{Relevant Literature}

The subliminal issues of sensuality and sexuality and their imbrications in the imperial project profoundly impacted colonial governmentality (see Ronald Hyam's (2008) essay on "Concubinage and the Colonial Service: the Crewe circular 1909"). These issues become evident and perhaps significantly more pronounced in the narratives deriving from and reflecting the colonial condition and imperial domination. Regarding the British empire, Hyam (1986) claimed in his writing in 1986 that the history of sexuality in Britain had been rewritten, but that "the historians of empire have made no such parallel contribution... [being] extremely shy of putting "sex" on their agenda" (34). This comment was provocative enough and through the next decade a number of publications appeared on colonialism, race and sex. Hyam is one of the major writers on sexual relations between the colonizer and the colonized which he called "sexual opportunism built into colonialism." According to him, "sexual dynamics crucially underpinned the whole operation of the British empire and Victorian expansion" (Hyam, 1990: p. 1) and suggests that the imperial administration may have used sexual relations as central political mechanism to control its subject population. Along with its consolidation, the colonial administration faced certain imperatives regarding the stay of its officials in India. For example, there was a demand for domestic help that the "natives" would provide and the administration also had to concede sexual access to native women. Hence, to a certain extent the presence of "native" men and women around military cantonments and colonial settlements, as well as liaison with public women were accepted (see Pran Neville, 2009 on "nautch" girls and prostitutes) to meet the domestic and sexual requirements of the British officials in India whether with or without their families. Mark Harrison (1994) remarks that given such circumstances, the "Contagious Diseases Act of 1859" meant to control venereal diseases based on a study on public health in the Indian Empire, may have suggested restrictive and punitive measures (73). The laws promulgated by the administration and upheld by 
their Courts acknowledged the domestic-sexual arrangements but were carefully structured to uphold and legitimize the existing heirarchy of colonial power of control over all arrangements and relationships with the native subjects. In her critique of imperialism while discussing three women's texts, Gayatri Chakravorty Spivak (1985) refers to "the planned epistemic violence of the imperialist project" that was all too often backed up by the planned institutional violence of armies and law courts, prisons and state machinery (248). Durba Ghosh's (2006) detailed analysis of sex and family under the colonial dispensation discusses the financial compensation for the anglo-native relationships that the administration was forced to take cognizance of, especially the mixed raced offsprings of the native women "companions" of the sahibs(which gave birth to a hybrid race of Eurasian/Anglo-Indian community in India. See Frank Anthony, 1969). Robert Clive's "Pension Fund and Military Orphan Society" serves as an example. Ghosh writes that the anxiety of the colonial administration to educate the mixed race children and make them loyal and productive subjects of the empire was however not shared by Britain.

\section{Socio-Cultural Impact of Colonialism in India}

In his book on the subject Kenneth Ballhatchet (1980) writes that anglo-native liaison decreased after the 1857 Sipahi Uprising when a strict segregation was put in place leading to a kind of "sexual apartheid". This may have been due also to the arrival of a large number of European women and the Evangelical attitudes of contempt and superiority towards Indian culture. Reviewing Ballhatchet's book, Eric Stokes (1980) comments that the racial savagery that overtook British and even American opinion after the Outbreak of 1857:

...was seen as the crude and brutal assertion of superiority by "civilization" over "barbarism"- or what Macaulay liked to call the strength of civilisation without its mercy.... There was now an enlarged European community that felt much less secure psychologically and materially. Drawn in part from the British lower-middle classes, it found itself thrust into positions of unaccustomed authority and affluence, and yet compelled to live in conditions of legal equality and growing competition with an often highly-educated Indian élite. The assertion of European superiority was steadily to renounce the rough hand (or boot) of the master-servant relationship and resort to the quieter and deadlier psychological warfare of preventing social mixing by excluding Indians from clubs and inflicting other such snubs... (17).

He ironically adds that "E.M. Forster's Chandrapore was just around the corner"! (17). Anne Laura Stoler (1997) explains that "colonial authority was constructed on two powerful, but false, premises. The first was the notion that Europeans in the colonies made up an easily identifiable and discrete biological and social entity; a "natural" community of common class interests, racial attributes, 
political affinities and superior culture. The second was the related notion that the boundaries separating colonizer from colonized was thus self-evident and easily drawn" (635). The colonial politics of exclusion was contingent on constructing categories, legal and social classifications designating who was "white," who was "native," who could become a citizen rather than a subject, which children were legitimate progeny and which were not (Stoler, 1997: p. 635). Stoler writes that neither premise reflected colonial realities.

\section{Research Focus}

The texts selected for discussion in this paper are from the twentieth century when the British imperial control in India had begun to face nationalistic struggle, yet held strictly on to colonial policies of racial segregation. They draw upon the relationship of the colonizer and the colonized that presents a complex interweave of race, sex and colonial law in the post-1857 scenario. Soon, conflicting economic and political agendas, frictions over colonial privilege and power, anti-imperialistic attitudes heightened the tension in the anglo-native relationships. The interesting point the texts make evident is that desire and sexual gaze were reciprocal. The colonizer and the colonized succumb to mutual attraction and desire despite authorities and laws prohibiting such desire. The resulting complications obviously provoke political ramifications that impact the master-subject/ruler-ruled and British-Indian relationships. That this was not confined to India is clear from the consequent research that was undertaken in the latter part of the century and 1995 saw the publication of three investigative studies on "colonial desire" and its implications by Anne McClintock (1995), Ann Laura Stoler and Robert C. Young (1995). The studies, located in postcolonial discourse, combine methods from literary criticism, anthropology, political economy and psychoanalysis to focus on Europe's possessions in namely South America, Africa, and the islands of the Pacific Ocean.

\section{Methodology}

The essay is planned as a critical analysis of literary evidence that how historical forces of colonialism divided the people by driving an insidious wedge between them on the basis of race and sex. It also studies laws formulated by the colonizers to serve this aim.

\section{Discussion: India as a British Dependency}

India was not the first colony in the British empire, nor was it the last to win independence; but in can be confidently asserted that it was in India, more than in any other place, that British colonial practices were redefined and sharpened for imperial governance in their territories around the world. The moral and cultural justifications and ethical compromises that guided the British Raj in India during 18th and 19th century became central to Britain's own changing understanding of itself. For Britain, India was not just another colony, but "always 
something more: a mental construct, a poetic trope, a fictional mirror" (Walsh, 1999: p. 21) that reflected British notions of political sovereignty, moral and cultural supremacy, as well as the right and rightness of British rule. As such, the vast and exotic terrain called India held a special place in the British mind as the jewel in the crown of an empire, literally and figuratively, so much so that Lord Curzon proclaimed in 1901, "As long as we rule India we are the greatest power in the world. If we lose it we shall drop straightaway to a third-rate power" (quoted by Judd, 2004: p. 101).

\subsection{Desire Motivating Colonialism}

I argue in this paper that "desire" as a driving force to fulfill a "lack" and seek its subject in the realm of the real applies to human action of many kinds. This idea combines the essential insights from the metaphysical discourse formulated from Plato to Kant with psychoanalytical concepts forwarded from Freud onwards as "desire and unconscious" or "the unconscious as desire" to which many philosopher-psychologists have contributed. After Freud, Jacques Lacan's (1981) definition emphasizes "desire for the Other" $(235)^{1}$ while Deleuze and Guattari (1972) extend the idea of "desire" (perhaps led by Marxist thoughts) to show that desire does not emerge merely as "lack" but produces a direction and that the subject missing/lacking in desire is not some fantastical object. Drawing insights from Nietzsche's Genealogy of Morals, Deleuze and Guattari (1972) see colonialism as a field of desire and will [to power], of the conscious and the unconscious forces that relate desire directly to the social field and to a monetary system based on profit. They explain in Anti Oedipus. Capitalism and Schizophrenia,

If desire is the lack of the real object, its very nature as a real entity depends upon an "essence of lack" that produces the fantasized object. Desire [is] thus conceived of as production... On the very lowest level of interpretation, means that the real object that desire lacks is related to an extrinsic natural or social production, whereas desire intrinsically produces an imaginary object that functions as a double of reality, as though there were a "dreamed-of object behind every real object," or a mental production behind all real productions. (48)

Thus "lack" operates as a residuum of desire located in the real and the social, combining the intrinsic with the extrinsic. So "desire" becomes a fundamental motivation for "colonialism" and feeds imperial ambitions for commercial gain, territorial and political control and exercise of military power-all seeking to be justified by an attitude of civilizational, ideological, moral and religious superiority, as John Dewey (1927) once remarked, "Imperialism is the result, not just

${ }^{1}$ Lacan's (1981) theory of desire appears to have two poles: one related to "the object small a" as a desiring-machine, which defines desire in terms of a real production, thus going beyond both any idea of need and any idea of fantasy; and the other related to the "great Other" as a signifier, which reintroduces a certain notion of lack. In Serge Leclaire's article "La re'alite du desir" (Ch. 4, reference note 26), the oscillation between these two poles can be seen quite clearly. 
a purpose or plan" (np).

The genealogies of colonialism provide evidence of the way the play of desire and sexuality precipitated the structuring of codes and laws to control colonial relations and the cases of inter-racial liaisons make clear how culture carried within it an inner dissonance. From the stories of Rudyard Kipling to novels like E. M. Forster's Passage to India, Paul Scott's Raj Quartet and others, the fictionalized lives of British colonialists in India as administrators and judges, army officers, traders, planters, and evangelists along with their wives, daughters, sisters and visitors from home, contributed to British self-perception and attitude towards Others, exerting more profound influence on British sentiments than perhaps any other colony. British colonial rule in India thus helped Britain to aspire to and achieve their deepest desires even as the colonialists sought to remake India.

\subsection{Colonialism, Sexuality and Law}

This paper focuses on the multifaceted intersections of colonialism, sexuality and law as presented in three fictional works which review British imperialism in India. E. M. Forster's (1924) A Passage to India, Paul Scott's Jewel in the Crown (1983), the first of the four-novel series called the Raj Quartet written between 1966-1975, and Top Stoppard's Indian Ink presented as a stage play in 1994 (adapted from the earlier radio play titled In the Native State 1991) cover almost the entire twentieth century, one is written during colonial time, the other two straddle colonial and postcolonial periods. The stories stage the complex linkages between race, sex and law in colonial India. Structurally too, they seem to echo each other; Scott's and Stoppard's texts appear like sequel to Forster's explorations into the psycho-social dimensions of colonial relationships. The narratives are organized in sections or parts to separate the Races, thereby endorse and freeze the hegemonic differences. This gets reflected in the division of the town sectors as appropriate for the regulation of inter-racial interactions in different spaces. The characters too are placed in separate camps of the ruler and the ruled and the twain do not appear to meet! But there are certain characters who are allowed to transgress these impositions. They are uncomfortable with the tensions and antagonistic binaries of reason and emotion and hence operate as centres of gravity and middle-markers to question the hierarchical power relations and the rigidity of demarcation of the colonizer and colonized. They make efforts to build bridges of understanding as if to compensate for their "colonial" guilt. But as the narratives show, the mediating presence of such characters does not make much impact as though to say that compromising the separateness of racial identity is not acceptable to either group.

The three stories are located in fictional towns in unnamed provinces of India. Chandrapore, Mayapore, Jummapur are all sites of violent confrontations between the British rulers and the Indian ruled. The basis of the conflicts is transgression of racial restraint in sexual relationships that attract the intervention of 
law. In my view, all three narratives endorse Foucault's constructivist perception of the relationship of sexuality and power. Additionally, all three texts have visual adaptations.

\subsection{Narratives and the Play of Desire: A Passage to India}

The three selected texts are familiar and much discussed. The paper will focus on the issues of racial confrontation and its interpolation in the discourse on race, sex and law in colonial India as made manifest in the texts.

CHANDRAPORE: $A$ Passage to India (1924)

The novel opens with a mundane description of the town Chandrapore on the banks of the river Ganga that has nothing spectacular in it other than the Marabar Caves twenty miles away. The developing narrative shows the segregated living areas which seem to anticipate the final violent and climactic racial clash. The poverty of the lowest tier of the town is emblematic of the lives of the impoverished native population. The second tier indicates areas of the town inhabited by better placed Indians. The houses of the Eurasians separated from others "stand on the high ground by the railway station" (1). Only the uppermost tier occupied by the British residents exhibits any level of affluence. This is indicated by the well-laid out roads with lights to contrast with the chaotic parts of the town where the natives live. The roads are "named after victorious British generals and intersecting at right angles, were symbolic of the net Great Britain had thrown over India" (5). The separation of races, classes, and religions of the inhabitants is clear and the political hegemony, and the power imbalance is quickly established. The time of the story is uncertain, perhaps reflecting India of 1912, the time of Forster's first visit, or anytime between 1912 and Forster's second visit in 1919 after the Jalianwala Bagh Massacre when anti-colonial reaction had reached a volatile pitch. Forster explains his intention and his subsequent frustration for writing the novel. In a letter to Syed Masood on the 27th of September 1922, he states: "When I began the book I thought of it as a little bridge of sympathy between East and West, but this conception has had to go, my sense of truth forbids anything so comfortable. I think that most Indians, like most English people, are shits, and I am not interested whether they sympathize with one another or not" (quoted in Furbank, 1978: p. 106). Much of the book is conversation among social groups trying to make sense of the actions-reactions of the other social groups. The mutual puzzlement about behavioral codes of each group can be justifiably attributed to cultural difference. But the conversations aren't matters of mere curiosity but constitute a social process-of creating difference and oppression, comprising talk about the inferiority of the Indians and the magnanimity and justice of the British colonizers ruling India to help Indians. The central question the story poses is whether Indians can be friends with the British colonizers.

The narrative begins with the arrival of Mrs. Moore with Miss Adela Quested who has come to meet Mrs Moore's son Ronny Heaslop, the local magistrate, before they decide to marry. While visiting the British club restricted to the 
Whites only, Mrs Moore wanders into a mosque and meets Dr.Aziz there, a young Muslimlocal doctor. They get acquainted and a hesitant empathy develops. Ronny Heaslop is not pleased when his mother speaks well of the Indian Muslim doctor but Adela shows interest. Later, in a party organised by the tax collector Mr. Turton, Mrs. Moore and Adela meet other local inhabitants like Cyril Fielding the headmaster of the small college for Indian students, the Hindu-Brahmin professor Narayan Godbole, Dr. Aziz and other Indians. The new visitors learn the difference in religious practices of Hindus and Muslims. The gathering is awkward as the racial divisions and prejudices are not erased. The story recounts several prior or subsequent incidents and instances which underline the uneven relationship between the two races, ranging from the colonizers' downright insulting, dismissive and patronizing attitude to some others' friendly open-minded understanding. Mrs. Moore and Fielding belong to the latter group and try to counterbalance the general British hostility towards the "natives". For instance, in a conversation with his mother, Heaslop says,

"We're not out here for the purpose of behaving pleasantly!"

"What do you mean?"

"What I say. We're out here to do justice and keep peace. Them's my sentiments. India isn't a drawing room."

"You're sentiments are those of a god," she said quietly, but it was his manner rather than his sentiments that annoyed her.

Trying to recover his temper, he said, "India likes gods."

"And Englishmen like posing as gods."

“There's no point in all this. Here we are and we're going to stop, and the country's got to put up with us, gods or no gods..." (Ch V, 21)

Crisis develops when Dr. Aziz, persuaded by the British visitors' touristic interest, organizes as a gesture of hospitality a trip to the famous Marabar Caves. No one seems to know much about the caves. Godbole may know, but doesn't elaborate. Once there, Mrs. Moore is distressed by the sultry darkness and the booming echoes of the caves and refuses to explore further. Adela enters another cave alone. Aziz can't find her. Something unexplained happens in the caves and she rushes out, disoriented and hysterical, with scratches on her body, and is taken away in a car by Miss Derek who thinks Aziz has raped her. A perplexed Aziz returns by train with Mrs Moore and Fielding. Confused, traumatized and ill, Adela is comatose. It is assumed by Chandrapore British contingent that Adela Quested was sexually assaulted by Aziz in the caves. The issue sharpens the racial antagonism and hostility as the Indians claim Aziz's innocence and the British insist on his guilt. Aziz is arrested and a trial ensues. Although Adela had not endeared herself to the British officials and their wives, they rally around her now to denounce Aziz because she is "an English girl, fresh from England" and he a heathen Indian. Two individuals who appear to be on Aziz's side are Mrs. Moore and Fielding. Sensing her sympathies, Heaslop, the local magistrate, sends his mother away before the trial. Mrs. Moore dies on the ship. Initially the 
trial does not seem to go well for Aziz as the British summoned as witnesses prevaricate to accuse Aziz. Meanwhile, Adela recovers and states in Court that Aziz did not follow her into the cave and therefore there was no assault. Aziz is freed of all charges but feels bitter and deeply betrayed. Though Adela is hailed by the Indians, she is spurned by her own people, the British of Chandrapore who believe she has renounced their cause. Heaslop distances himself from her. She is befriended by Fielding. One could say Adela's traumatic experience in the caves might represent the culmination of a series of minor crises in her life after coming to India, including her relationship with her fiancé Ronny Heaslop. Aziz continues to harbor ill feelings towards her for bringing shame upon him and becomes suspicious of Fielding's intentions for sheltering her. So the tenuous friendliness between them is ruptured. Adela departs for England and Aziz mistakenly believes that Fielding, who also goes to England, has married her. His mistake is corrected at the end of the story. Meanwhile Aziz answers the rhetorical question he had posed himself that Indians can be friends with the British only on equal terms, that is, after India was free of colonial shackles.

\subsection{Narratives and the Play of Desire: The Jewel in the Crown}

MAYAPORE: The Jewel in the Crown (1983)

This novel, the first of Paul Scott's Raj Quartet series, is set in 1942 in Mayapur, a fictional town located in the agricultural plains with a mountainous region to the north recalling features of Punjab and north provinces of India, though some names of places and people also suggest connections with Bengal. Mayapore has a cantonment area where the British stay and native Indians work but aren't permitted to live. Beyond the rail tracks lies the "black town" where the native population resides. There is also a Eurasian Quarter for the mixed-race people. The narrative explores the historical context and the socio-political ramifications of the British presence in the country fuelled by the colonial desire for unbounded resources and power. The story unfolds during the political upheaval of 1942 when Gandhi's "Quit India Movement" enhanced racial antagonism and widespread violence. The narrative begins as a" story of rape, of the events that led up to it and followed it and of the place in which it happened. There is the combination of action, people, and the place; all of which are inter-related yet in their totality incommunicable in isolation from the moral continuum of human affairs" (1). An unnamed Englishman as the narrator says that the case of rape of an English woman was never satisfactorily solved due to the political climate of the time and hence merits a re-look which could reveal the subliminal layers of emotional, racial and political complexity. The narrative style derives from this aim. Points of view shift intermittenly and incidents are presented as documentation of facts interspersed with excerpts from Daphne's chatty letters to her aunt, and conversation among the characters to explain their perspectives and situations.

The story is of a young Englishwoman named Daphne Manners, an orphan, 
visiting her aunt in Lahore who thinks Daphne will have better chance of meeting people and seeing places if she stays with Lady Chatterjee in Mayapore. Daphne, a rather plain looking person, settles down in Mayapore and soon falls in love with an Indian Hari Kumar, who grew up in England and has returned to India after his father's death. He works for the town newspaper. Their relationship isn't regarded well when Europeans and Indians remain racially segregated, live in separate parts of the town and socio-political tension pevails between them. Daphne's preference for Hari Kumar angers Ronald Merrick, the local Police Superintendent, who had once asked Daphne to marry him. Merrick's prejudice against Hari is strengthened by Hari's public school education against Merrick, a mere a grammar school boy: "the blond, blue-eyed Merrick and the dark-skinned, brown-eyed Kumar who says with an English Public school accent, "I'm afraid I don't speak Indian" (143). Scott comments that "Two such darknesses in opposition can create a blinding light. Against such a light ordinary mortals must hide their eyes" (146). Daphne and Hari meet one night in the secluded park Bibighar Gardens where they make love for the first time. They are attacked by a group that beats up Hari, ties up Daphne and rapes her. Fearing that Hari will be blamed for the crime, Daphne makes him promise not to admit being with her. But as soon as the sexual assault is reported, suspicion falls on Hari who is promptly arrested by Merrick along with several of his friends from Mayapore Gazette. It is assumed that the rape was racially motivated. Hari being an Indian is accused by the British and Daphne becomes the target of Indian prejudice as a white woman having sex with an Indian. Daphne refuses to co-operate in the prosecution of Hari and others arrested with him. There is no legal trial in the judicial sense, but a trial of sorts on those assumed guilty embroils the people:

In fact, such people say, the affair that began on the evening of August 9th, 1942 , in Mayapore, ended with the spectacle of two nations in violent opposition, not for the first time nor yet for the last, because they were then still locked in imperial embrace of such long standing and subtlety, it was no longer possible for them to know whether they hated or loved one another...." (1).

In the absence of strong evidence, the rape charges are dropped against Hari and his friends, but they are deliberately implicated in political crimes as revolutionaries against the British and are incarcerated under British war laws. The Mayapore incident leaves an insidious impact on the widely spreading "Quit India" riots that end in Mr.Choudhury's death and Bibighar Gardens being burnt by Edwina Crane, the two persons who had made friendly overtures to supercede race. Daphne is regarded a traitor to her people for protecting the native "rapists." Daphne continues to love Hari. She becomes pregnant and wishes to present him with their child but doesn't survive the childbirth. The child Parvati's physical resemblance to Hari satisfies both Lady Manners and Lady Chatter- 
jee that Hari is her biological father.

It is a volatile time of political unrest. Gandhi has escalated the Non-cooperation Movement and the British has been defeated by the Japanese army in Burma. In reaction, the colonial administration is determined to suppress all political resistance in India. This is the backdrop of the story when tensions run high and political, racial, religious differences create a dangerous and uncertain environment. Race and class prejudices are the central themes and drive the diegetic development.

\subsection{Narratives and the Play of Desire: Indian Ink}

\section{JUMMAPUR: Indian Ink (1994)}

Stoppard's play presents two time-periods. The first story is set in 1930 colonial India, the year of Gandhi's Salt March when Flora Crewe, a 35-year-old bright young thing who has modeled for Modigliani, hobnobbed with communists, and penned risqué poetry that makes her (in)famous in England, arrives in Jummapur to recover her health, as she suffers from severe tuberculosis. Ostensibly she is a guest of the Theosophical Society of the town invited to deliver some lectures on British literary life. Jummapur is a fictitious town which shows racial segregation between the British and the Indians although Flora Crewe is cordially welcomed at the station with marigold garlands by Coomaraswamy the president of the Theosophical Society and other members. She is escorted to the government circuit house with the promise of a touristic visit to the temples and a picnic the next day. Her lectures are a big hit with the Anglophile Indian elites who lap up her gossipy accounts of London activities. While at Jummapur, Flora fends off the attentions of the dashing but dimwitted "British Resident" David Durance who "quizzes her" on her motive for coming to India and after few meetings and dances proposes marriage. She also rebuffs an Indian prince who wants to show her off as he does his stable of cars. During her talks, she meets a shy young painter Nirad Das who shows his sketch of her made while she was speaking. He presents it to her with his signature. Flora is pleased and flattered when Das wants to paint her portrait. He comes to the guest house next day with a gift of a vintage copy of Emily Eden's 1866 collection of letters, Up the Country. He begins his painting while Flora tries to write poems. But unable to write poetry in the intense heat, shespends time writing informative letters to her sister Nell in London. She is disappointed with Das's painting and chides him for "Englishing" her instead of painting her in the Indian style. She invites him to paint her in the nude. Nirad explains to her the theory of rasa, especially the elements of shringararasa of erotic love along with the context of the lover and his beloved and the symbolic detailing of the moon, the woods and scent of sandalwood. He also explains the tradition of narrative art and rasa as the guide to art appreciation. Flora wants to imbibe the aspects of erotic love in the poem she is writing. Soon, however, Flora's ill health forces her to go away to a hill station where she eventually dies. Years later, Nell visits her grave.

The second time-period of the play is the 1980s. An American editor Pike 
wants to publish Flora Crewe's letters to her sister Eleanor Swan (Nell) with detailed footnotes. He visits her for details about them and direction. He is aware a painting exists and would like it to make it the cover of the book. Eleanor is also contacted by Nirad Das's son Anish Das who seeks information about his father's relationship with Flora Crewe, and explains that soon after he met Flora his father was arrested and jailed for an undisclosed reason. He was released but never recovered from the shock. Eleanor is sympathetic with Anish and shows him Nirad Das's sketch and the nude painting of Flora. The painting's erotic symbolism convinces Anish that his father and Flora were lovers, explaining to Nell that Hindus like his father painted in the language of symbols as for example the open book on Flora's bed as a symbol of who Das thought she was, and the tree with falling leaves as a symbol of years falling by or imminent death. Anish says his father left the oil painting incomplete and began a nude water colour of Flora Crewe and shows it to Eleanor. Both decide not to mention these details to Pike.

\section{Intertextual Connections}

The three texts appear intertextually connected, as though speaking with each other. They focus on complicated relationships not only between the colonizer and the colonized but also among the members of each group and share similar colonialist $^{2}$ preoccupations. Certain colonial motivations and stereotypes are replicated-for example, Callendars and Turtons of Forster are the Tuptons of Scott representing a class of colonizers who create racial distance and prejudice. There are also characters who follow their heart or conscience against terrible odds, some even losing their lives in that pursuit, compassionate people like Mrs. Moore, Cyril Fielding, Daphne Manners, Ludmilla Smith, Edwina Crane to some extent, Flora Crewe and Eleanor. The novels mention missionaries who profess to be racially unbiased but retain and demonstrate cultural and civilizational superiority. There are also the Eurasians, distinguished from Indians. Located at the core of Forster's story is the enigmatic void of the Marabar Caves with its Freudian imagery of snakes, bats, darkness and the booming echo. Forster seems to suggest that the caves represent India's complexity, ambiguity and eternal puzzle. He writes in the novel, "India calls 'Come' through hundred mouths, through objects ridiculous and august. But come to what? She has never defined. She is not a promise, only an appeal" (136). Similar dark mystery is hinted at in Jewel in the Crown: "Imagine, then, a flat landscape, dark for the moment, but even so conveying to a girl running in the still deeper shadow cast by the wall of

\footnotetext{
${ }^{2}$ Nadine Gordimer (1974) explains that "a colonialist is one who advocates the policy of colonization; further, he may be one delegated, within the Colonial Service, to administer that policy, a colonial functionary in the European power's governance of territory taken by conquest of the original inhabitants. He is not a citizen of that territory, his country remains one across the world. A colonizer is a settler in the conquered territory, coming from another country but taking up residence and citizenship (usually granted after a period specified by the colonialist power). He occupies and owns, either under a settler dispensation to extend the "mother" country's domains, or purchased from it, land taken by that colonialist power from the indigenous people. The colonizer regards himself as a permanent inhabitant. The difference is important" (30-31).
} 
the Bibighar gardens an idea of immensity, of distance..." (1). Scott's story highlights the inherent violence that accompanies the desire to transgress racial taboo. The Bibighar Gardens incident spreads its tentacles over the lives of several people as political antagonism and hostility escalates in tandem with the socio-cultural one, as Daphne says, "Well, Hari and I are the exhibits too". We could stand here on a little plinth, with a card saying "Types of Opposites: [male sign] Indo-British, circa 1942. Do Not Touch. Then all the people who stared at us in the cantonment, but looked away directly we looked at them, could come and stare to their hearts' content" (382). Being the introductory volume, the narrative holds promise of future closure in the sequel. Stoppard's story is of exploration of a relationship that may have been intimate but is not in obvertly violent. The subtly changing relationships are traced through the two time-scales, always with the awareness that the painting of an Englishwoman in the nude by an Indian would have been scandalous had it become known, certainly leading to racial repercussions. Nirad Das is arrested shortly after Flora Crewe's departure, although his friendship with Flora is not mentioned as the reason. All three recount the intervention of British law to ensure that the twain West and East should never meet.

\subsection{Theorization}

The narratives have been discussed at great length in critical studies on colonial literature. Those arguments need not be reiterated here. But one viewpoint is of relevance to this paper. In his essay on "The Economy of Manichean Allegory: The Function of Racial Difference in Colonialist Literaure," Abdul Janmohamed (1985) writes, "The perception of racial difference is, in the first place, influenced by economic morives" (61). According to him,

Colonialist literature is an exploration and a representation of a world at the boundaries of civilization, a world that has not (yet) been domesticated by European signification or codified in detail by its ideology. That world is therefore perceived as uncontrollable, chaotic, unattainable, and ultimately evil. Motivated by his desire to control and dominate, the imperialist configures the colonial realm as a confrontation based on differences in race, language, social customs, cultural values and modes of production. (64)

He calls colonial societies deeply "pathological societies" (80) and summarizes the colonial situation thus:

If every desire is at base a desire to impose oneself on another and to be recognized by the Other, then the colonial situation provides an ideal context or the fulfillment of that fundamental drive. The colonialist's military superiority ensures a complete projection of his self on the Other: exercising his assumed superiority, he destroys without any significant qualms the effectiveness of indigenous economic, social, political, legal, and moral systems and imposes his own versions of these structures on the Other. By thus subjugating the native, the European settler is able to compel the Oth- 
er's recognition of him and, in the process, allow his own identity to become deeply dependent on his position as a master. This enforced recognition from the Other in fact amounts to the European's narcissistic self-recognition since the native, who is considered too degraded and inhuman to be credited with any specific subjectivity, is cast as... a recipient of the negative elements of the self that the European projects onto him. This transitivity and the preoccupation with the inverted self-image mark the "imaginary" relations that characterize the colonial encounter. (66-67)

Janmohamed categorizes two kinds of colonial writing: the "imaginary" and the "symbolic" (65). In the "imaginary" text, the emotive as well as cognitive intention alities are structured by "objectification and aggression", accompanied by the adamant refusal to admit possibilities of rapprochement between the Self and the Other. The "symbolic" text, of which these three selected texts can be taken as examples, attempts to find "syncretic solutions to Manichean oppositions between the colonizer and the colonized" and makes an effort to overcome the barriers of racial difference" but are unfortunately "seduced by the specularity of 'imaginary' Otherness" (66). Such complications are bound to happen as colonialism breeds "Otherness". According to Albert Memmi (1974), the colonizer "discovers the existence of the colonized as he discovers his own privilege.... He finds himself on one side of a scale, the other side of which bears the colonized man... [T] he more freely he breathes, the more the colonized are choked... It is impossible for him not to be aware of the constant illegitimacy of his status" and the illegitimacy of colonization as a double one (51-52). The colonizer finds a place to settle into by taking away that of the inhabitants.

\subsection{Rule of Law}

The three narratives reveal the socio-psychological tensions of unequal relationships that not only frustrate all attempts of friendship between the colonizer and the colonized. The escalating tensions arising out of the sexual liaisons [real or imagined] between individuals belonging to the two groups lead to irruption and outbreak of violence. All the three stories with "administrator sentinel figures" to safeguard racial separateness can serve as models for the study of the functioning of colonial law in the empire. The Rule of Law at the heart of the English colonial enterprise in India and other settler colonies refers to the general principle that all laws should apply equally, unconditionally and forcefully to all people to ensure consistency, order and control. Albert Venn Dicey (1835-1922), a British jurist and constitutional theorist, popularized the concept of Rule of Law, which for him meant three things: "the legislative sovereignty of Parliament", "the universal rule or supremacy throughout the constitution of ordinary law" and "the dependence in the last resort of the conventions upon the law of the constitution" (see Principe, 2000). The lofty aims suggest that rule of law was more than a synonym for law and order and meant upholding the supremacy of the British legal system and administration. During the consolidation of empires, Western 
concepts of law were deeply embedded in both the practice and the propaganda of imperialism. As the British Empire extended its reach, "inventing" legal conventions became necessary to govern the White dominions and dependent territories. Thus, Rule of Law became part of a highly politicized vocabulary employed in such debates as Irish Home Rule. The logic was that those who could not regulate themselves required regulation from the outside. Such regulation was supposed to be benevolent, not coercive. Dezalay and Garth quote the Rudolphs saying, "For most Englishmen, having established the 'rule of law' in the Indian subcontinent was probably the proudest achievement of the British raj" (cited by Dezalay and Garth, 2010: p. 65), although the efforts began much before the official creation of the Raj in 1859. Hence, law-making was conceived as an assisting instrument for colonial administration. James Fitzjames Stephen (1872) contextualized the colonial Rule of Law by arguing that law was "an absolute government, founded not on consent but on conquest" (55). Stephen (1872) also formulated the Indian Evidence Act that sought to consolidate rules of proof and invest them with legislative authority. The Act set in place throughout the Indian colony instructions regarding the admissibility of evidence. Before the passage of the Act in 1872, rules of evidence differed among ethnic groups, caste, community, and region. But for law theorists like Stephen, legal diversity would mean chaos for the administrator; so Stephen promulgated a utilitarian code of law, as Rules of Evidence. However, colonizers' law was exclusive of and discriminatory towards the colonized who had little say in its constitution. From the point of view of the "ruled", Stephen's "Rule of Law" was highly problematic, implying a monolithic structure presiding over various groups that can neither change that structurenor question its promulgations. Each of the selected texts shows the contexts arising from draconian laws like the Evidence Act and the Rowlatt Act that provoked revolutionary reaction, the Dandi March, Quit India Movement and so on. Clare Midgley (1998) admits that the Rule of Law was a tactic for achieving colonial hegemony leading to "a reorganization of the civil society of the colonized [...] through a diffusion of cultural ideological constructions and moral regulations" (21). She claims that "this legitimation aspect of hegemony is present in most colonial enterprises to varying degrees depending on the nature of the enterprise, it is the case with India that British colonialism sought to legitimize itself through self-characterization as rule of law and social reform" (21).

\subsection{Narratives as Sites of Intervention}

It is clear that law figures at the heart of several English novels on colonial India which made manifest the English legal practice in the procedure described, the architecture and inner spatial arrangement of the courts, the garb of judges and lawyers, modes of address, and more importantly the boundaries between the colonizer and the colonized. Rule of Law operated generally on the basis of racial criteria restricting high judiciary to White men to regulate sexual, conjugal, and 
domestic life of both Europeans in the colonies and the colonized subjects. The incidents between Aziz and Adela Quested, Daphne and Hari Kumar, Flora Crewe and Nirad Das illustrate this process bound up with the "unlimited interest" of colonial participants in "the sexual interface of the colonial encounter," an interface that Stoler (1997: p. 635) characterizes as "European pornographic fantasies". The trial scenes become the sites for enacting exclusion policies where by Victorian sexual mores define and control colonial relations, and the conflict between reason and emotion both Indian and English culminates in the figurative recasting of British-Indian relations (discussed by Mendenhall, 2011). Discussing A Passage to India, Lauren Benton (2002) writes, "For the British community the upcoming trial is about protecting an Englishwoman from the contaminating and evil contact with an Indian and is thus about marking and protecting the lines separating the British and Indian communities"(152). Robert F. Aldrich (2003) explains, "The paradox for Forster as for others was that the imperial enterprise, complete with the idea of bringing civilization to the wider world, provided opportunities for a sexual emancipation that countermanded the moral order at home yet this does not happen" (325). Forster describes the Trial Court carefully giving attention to the spatial arrangements that makes the hierarchies clear so the sense of racial conflict Adela's alleged assault has triggered becomes more serious than Adela's welfare. The English focus solely on the vengeance to be had through Aziz's trial, ignoring both Adela's and Aziz's psychological trauma. The trial arouses emotions and divides the British and the Indians into two jeering groups. At best, the case appears to be based on circumstancial evidence with the decisive evidence being Adela's. She sits alone and stares distractedly at the servant pulling the fan, and thinks he looks beautiful, godlike, aloof from everything happening here. McBryde opens the case for the prosecution and presents as "scientific fact" his assertion that darker races lust after fairer races, but not vice versa, and adds that Aziz lives a double life simultaneously "respectable" and depraved. He cleverly ignores the real "facts" of the case. Adela becomes flustered when a voice in the crowd protests that Adela is ugly. Aziz's lawyer remarks on the absence of a witness Mrs Moore and hence the lack of important evidence. The presence of the English contingent on the platform as though to intimidate the witnesses is objected to by Amritrao, the lawyer from Calcutta and the Indian judge Das agrees that everyone but Adela must return to the floor, as though suggesting a level playing field. When called to give evidence, Adela states quietly that she made a mistake, Aziz never followed her and withdraws all charges. The courtroom erupts into two screaming abusing groups. The end of the story leaves a pervasive sense of emptiness, nothingness and loss when what is seen and what occur seem less significant than what is not seen or does not occur.

Two issues get intertwined in Scott's novel. The times are politically turbulent with riots everywhere. In this context, Daphne is found in the park with her Indian lover, is gang raped and Hari Kumar is arrested and tortured. Edwina 
Crane is forbidden by Indian friends not to be out of doors during the riots. She disregards the advice, convinced of her infallibility as a White woman. While driving back with Mr.Chaudhuri, when their car is surrounded by a rioting mob, Edwina wants to face the crowd, sure they will show respect due to her. She is not attacked but Mr. Chaudhuri is beaten to death as a traitor for befriending the English. Daphne and Edwina must go through such horrific experiences to realize that complacency about racial superiority is illusory, a creation of the White society, that critically impacts human relationships. Although there is no legal trial and the police are forced to release Hari Kumar, the English people of Mayapore indict both Daphne and Edwina Crane for not identifying those who attacked them.

Flora Crewe's last letter to her sister from Jummapur: "Darling, that's all from Jummapur, because now I'm packed, portrait and all, and Mr. Coomaraswami is coming to take me to the station. I'll post this in Jaipur as soon as I get there [...] something good happened here which made me feel halfway better about Modi and getting back to Paris too late. That was a sin I'll carry to my grave, but perhaps my soul will stay behind as a smudge of paint on paper, as if I'd always been here, like Radha who was the most beautiful of the herdswomen, undressed for love in an empty house" (44). A big part of the relationship between Flora and Nirad appears to be his instinctive understanding of her thoughts and awareness when she feels comfortable with him. Yet their relationship is tenuous and seems to break when she shows her disappointment with the painting. Nirad feels that since their artistic relationship is an extension of their feelings for each other, when she rejects his painting, she rejects him. She, on the other hand, feels this as cultural misunderstanding and the difficulty in forging a relationship that must transcend racial prejudices and cultural mismatch. After Flora leaves Jummapur the law intervenes to punish Nirad for daring to forge a relationship with a White woman. No other "evidence" is required.

\section{Conclusion}

The three texts seem to emphasize that the colonial Rule of Law as an authoritative system was flawed because it was founded on discrimination of Race and Gender. Yet, as claimed earlier, colonial laws still affect post-colonial conditions and several obfuscating laws continue to figure in the Indian Penal Code (IPC). First drafted by T.B. Macauley around 1860s and modelled on British laws, Louisiana Code of Law and the French Penal Code, the IPC has been amended many times since India's Independence and as many as 987 old and defunct "laws" of the Raj based on prejudice and discrimination have been repealed, including Criminal Tribes Act of 1871, Land Act of 1819, Foreign Recruiting Act of 1874, Elephant Preservation Act 1879 which levied Rs.500 for killing an elephant, as well as some bizarre colonialist laws. But even after changes and amendments made to the first copy of the document, the basic structure of the IPC remains the same as the last vestige of colonialism until it is further modified to meet the needs of India as a democracy based on equal rights of all its citizens. 


\section{References}

Aldrich, R. F. (2003). Colonialism and Homosexuality. London and New York, NY: Routledge.

Anthony, F. (1969). Britain's Betrayal in India: The Story of the Anglo-Indian Community. Bombay: Allied Publishers.

Ballhatchet, K. (1980). Race, Sex and Class under the Raj: Imperial Attitudes and Policies and Their Critics. London: Weidenfeld.

Benton, L. (2002). Law and Colonial Cultures. Cambridge: Cambridge University Press.

Bernstein, R. (2009). The East, the West, and Sex: A History of Erotic Encounters. New York, NY: Alfred A. Knopf.

Bryder, L. (1998). Sex, Race and Colonialism: A Historiographical Review. The International History Review, 20, 806-822. https://doi.org/10.1080/07075332.1998.9640841

Deleuze, G., \& Guattari, F. (1972). Anti-Oedipus. Capitalism and Schizophrenia. New York, London: Penguin Classics.

Dewey, J. (1927). Imperialism Is Easy (p. 50). The New Republic. https://groups.google.com/forum/\#!topic/alt.politics.socialism.trotsky/0aoFgtOkPY4

Dezalay, Y., \& Garth, B. G. (2010). Lawyers in the Shadow of Empire. Asian Revivals. Chicago \& London: The University of Chicago Press. https://doi.org/10.7208/chicago/9780226144665.001.0001

Forster, E. M. (1924). A Passage to India. https://archive.org/stream/ost-englishapassagetoindia/APassageToIndia\#page/n3/mod e/2up

Furbank, P. N. (1978). E. M. Forster: A Life. London: Secker \& Warburg.

Ghosh, D. (2006). Sex and Family in Colonial India: The Making of Empire. Cambridge: Cambridge University Press. https://doi.org/10.1017/CBO9781139878418

Gordimer, N. (1974). New Introduction. In Albert Memmi's the Colonizer and the Colonized (pp. 27-44). London: Souvenir Press.

Harrison, M. (1994). Public Health in British India: Anglo-Indian Preventive Medicine 1859-1914. Cambridge: Cambridge University Press.

Hyam, R. (1986). Empire and Sexual Opportunity. Journal of Imperial and Commonwealth History, 14, 34-90. https://doi.org/10.1080/03086538608582712

Hyam, R. (1990). Empire and Sexuality: The British Experience. Manchester: Manchester University Press.

Hyam, R. (2008). Concubinage and the Colonial Service: The Crewe Circular (1909). Journal of Imperial and Commonwealth History. http://www.tandfonline.com/doi/abs/10.1080/03086538608582718?src=recsys

Janmohamed, A. R. (1985). The Economy of Manichean Allegory: The Function of Racial Difference in Colonialist Literature. Critical Inquiry, 12, 59-87.

Judd, D. (2004). The Lion and the Tiger: The Rise and Fall of the British Raj 1600-1947. Oxford: Oxford University Press.

Kipling, R. (1889). Barrack-Room Ballads and Other Verses. London: Methuen \& Co.

Lacan, J. (1981). The Seminar of Jacques Lacan Vol XI: Four Fundamental Concepts of Psychoanalysis. New York \& London: W.W. Norton \& Co.

McClintock, A. (1995). Imperial Leather: Race, Gender and Sexuality in the Colonial Context. New York, NY: Routledge.

Memmi, A. (1974). The Colonizer and the Colonized. London: Souvenir Press. 
Mendenhall, A. (2011) Mass of Madness: Jurispridence in E.M. Forster's a Passage to India.

https://www.academia.edu/835525/Mass_of_Madness_Jurisprudence_in_E.M._Forster S_A_Passage_to_India?auto=download

Midgley, C. (1998). Gender and Imperialism. Manchester: Manchester University Press.

Neville, P. (2009). Nautch Girls of the Raj. New Delhi: Penguin Books.

Prasso, S. (2005). The Asian Mystique: Dragon Ladies, Geisha Girls, and Our Fantasies of the Exotic Orient. New York, NY: Public Affairs.

Principe, M. L. (2000). Albert Venn Dicey and the Principles of the Rule of Law: Is Justice Blind? A Comparative Analysis of the United States and Great Britain. Law Reviews. http://digitalcommons.lmu.edu/cgi/viewcontent.cgi?article=1498\&context=ilr

Said, E. (1978). Orientalism: Western Conceptions of the Orient. New York, NY: Random House.

Scott, P. (1983). Jewel in the Crown. London: Panther Books, Granada Publishing.

Spivak, G. C. (1985). Three Women's Texts and a Critique of Imperialism. Critical Inquiry, 12, 235-261. http://knarf.english.upenn.edu/Articles/spivak.html https://doi.org/10.1086/448328

Stephen, J. F. (1872). The Indian Evidence Act (I. of 1872) with an Introduction on the Principles of Judicial Evidence. Calcutta and London.

Stokes, E. (1980). The Road to Chandrapore. London Review of Books, 2, 17-18. https://www.lrb.co.uk/v02/n07/eric-stokes/the-road-to-chandrapore

Stoler, A. L. (1995). Race and the Education of Desire: Foucault's History of Sexuality and the Colonial Order of Things. Durham, NC: Duke University Press. https://doi.org/10.5040/9780571291946.00000004

Stoler, A. L. (1997). Making Empire Respectable: The Politics of Race and Sexual Morality in Twentieth Century Colonial (pp. 634-660).

https://deepblue.lib.umich.edu/bitstream/handle/2027.42/136501/ae.1989.16.4.02a0003 0.pdf?sequence-1\&isAllowed-y

Stoppard, T. (1995). Indian Ink. London: Faber.

Walsh, P. (1999). An Imperishable Empire. In Words on Plays, an Educational Guide to Indian Ink by Tom Stoppard Directed by Cary Perloff (pp. 21-23). San Francisco, CA: Amercan Conservatory Theatre.

Woan, S. (2008). White Sexual Imperialism: A Theory of Asian Feminist Jurisprudence. Washington and Lee Journal of Civil Rights and Social Justice Law, 14, 275-301. http://scholarlycommons.law.wlu.edu/cgi/viewcontent.cgi?article=1243\&context=crsj

Young, R. J. C. (1995). Colonial Desire: Hybridity in Theory, Culture, and Race. London: Routledge. 